\title{
Explaining Economic Improvement in Afganistan After Joining WTO: Neo-Liberal Institutionalism and Constructivism
}

\author{
Zhaoyang $\mathrm{Li}^{1, \mathrm{a},{ }^{*}, \dagger}$, Xueran $\mathrm{Qiao}^{2, \mathrm{~b}, *, \dagger}$, Xiangyi Song ${ }^{3, \mathrm{c}, *, \dagger}$ \\ ${ }^{1}$ University of Toronto, Toronto, ON M5S, Canada \\ ${ }^{2}$ Jiangsu Ocean University, Jiangsu, 222005, China \\ ${ }^{3}$ Beijing Foreign Studies University, Beijing, 100098, China

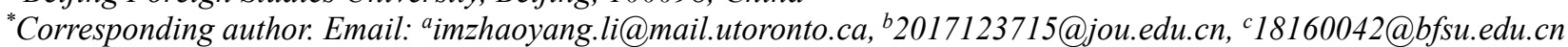 \\ These authors contributed equally.
}

\begin{abstract}
Afghanistan's economy is rapid developed since it has joined World Trade Organization (WTO) in 2016. In this paper, the Afghanistan's global economic improvement under the role of WTO, which has been observed recently, is explored based, on case study. Through the case study of Afghanistan, it offers a better understanding of the function of WTO. According to the results, Afghanistan's economic improvement can be explained by Neo-Liberal Institutionalism and Constructivism. This paper deepers our understanding of looking at the least developing countries' economic development and improvement from the perspectives of Neo-Liberal Institutionalism and Constructivism. Moreover, these results can be useful to policies recommendation that countries who would or could join WTO. Admittedly, there are limitations that Afghanistan is an extremely undeveloped country which may not explain most of the other countries in the world. Further studies should be focused on other countries' cases.
\end{abstract}

Keywords: Afghanistan, economy, WTO, Neo-Liberal Institutionalism, Constructivism.

\section{INTRODUCTION}

Generally, least developing countries (LDCs) improve domestic and global economy after joining a trade organization as WTO, though it is still controversy that whether it is the right decision for a country to join such an organization. Besides, the extent of the economic improvement from joining WTO is also puzzling with a controversial discussion. It is uncertain that LDCs can be competitive with other states and benefit from the competition. However, the impressive economic improvement of Afghanistan after joining WTO may answer the question but bring a new one that to what extent it can be attributed to WTO's influence, which has not been researched in detail.

With the development of globalization, a lot of countries has joined WTO for their economic development including Afghanistan, which is one of the LDCs. After more than 30 years of war and chaos, the economy has been destroyed. The transportation, communication, industry, education and agricultural infrastructure have been damaged seriously. There is a shortage of production and living materials, and more than 6 million people have been refugees. Since 2002, the national economy of Afghanistan has shown "low-level rapid growth", and the economy has gradually recovered. The WTO accepted Afghanistan's application for WTO entry in 2004. Since then, the country has held 11 years of WTO accession negotiations. In 2016, Afghanistan officially became the 164th member of the WTO. Afghanistan's accession to the WTO reflects its determination to integrate into the world economic development. According to World Bank Database (2021), the economic situation of Afghanistan has made obvious progress after 2016, and the reasons behind it are worth thinking about (e.g., the contribution of WTO) [1]. Furthermore, this case can help explain the role of WTO as an international organization in promoting the global and domestic economy.

As a matter fact, globalization increases the interaction between nation-states in an anarchy international society. On this basis, it is worth discussing the role of international organizations. This essay aims to verify the role of WTO in improving the domestic 
economy and world economy through the case of Afghanistan. It is unique because there is little research and literature about Afghanistan's economic development, as Afghanistan's accession to the WTO is not long. Moreover, these results can be significantly applying to other countries that have similar economic situations to Afghanistan.

The rest part of the paper is organized as follow. Section 2 will first provides information about Afghanistan economic background. Then, section 3 will explain this phenomenon from the aspect of the WTO institutional framework. Afterwards, section 4 will focus on ideological change. Subsequently, section 5 will analyse the perspective of concrete trade actions and performance. Eventually, a brief summary will be given in the Sec. 6 including limitation and further study.

\section{AFGHANISTAN ECONOMY BACKGROUND}

Afghanistan is recognized as one of the least developing countries (LDC) by the world, and it is a landlocked developing country as well (LLDC). The global power interrupted Afghanistan's development in 2001, and the government was re-established in 2002. Afghanistan's import is larger than the export, where some of the import goods are groceries. The majority of its export goods are handmade carpets and dry fruits. This country's imports were increasing from 2002 to 2012. Afghanistan's a dvanced industrial process technique process technique is lacking, i.e., it starts relying on foreign aid. To join WTO, Afghanistan reduces the tax for the sake of raising the credit. There is an export gap for this country and joining WTO might accelerate the export gap.

Compared with other LDCs (e.g., Nepal, Congo, Burkina Faso, and Uganda), Afghanistan has a lower tariff than them. Mobariz argues that to keep the low tariffs, the imported goods could be adorable and accessible for citizens [2]. After joining WTO, Afghanistan's imported tariffs might be lower. Afghanistan applied to join the WTO in 2003, and they had joined this institution till 2016.

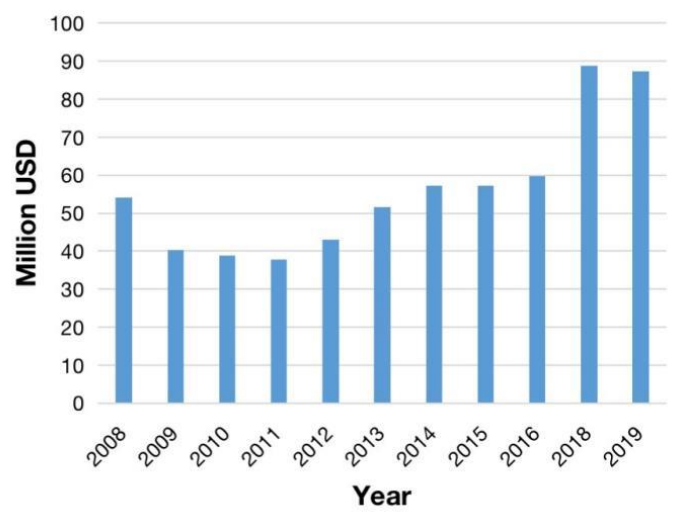

Figure 1. Export in Afghanistan from 2008 to 2019 (Million USD) Source: TrendEconomy [3]

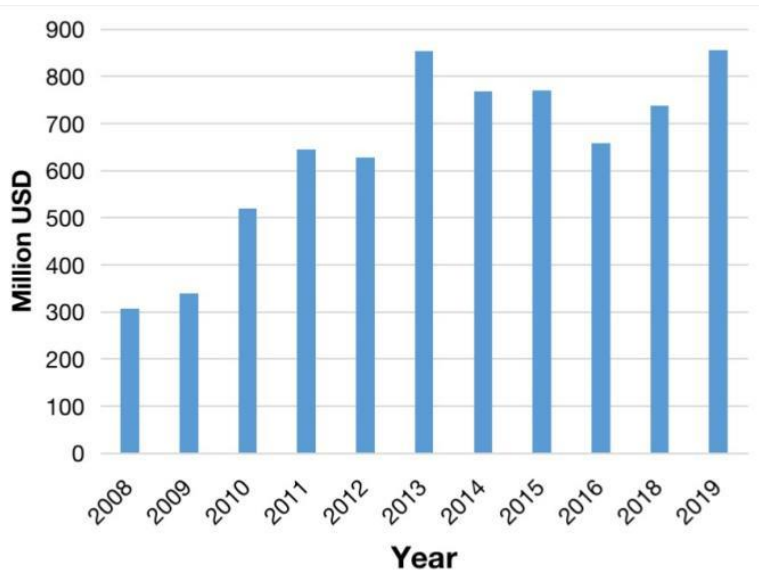

Figure 2. Export in Afghanistan from 2008 to 2019 (Million USD) Source: TrendEconomy [3]

According to TrendEconomy, the above two figures show the import and export value change of Afghanistan [3]. Seen from Fig. 1, after Afghanistan joined WTO, its export value was increasing rapidly from around 59 million USD (US dollars) in 2016 to nearly 89 million USD in 2018. As shown in Fig. 2, Afghanistan's import value increased stably from 2016 which was around 653 million USD to 2019 which reached its peak at 965 million USD. Since the entering of WTO, both of this country's import and export value has increased, and clearly, the import value is much larger than the export.

Within Afghanistan's low economic development and poor political situation, joining WTO could help this country to develop its economy. Specifically, it can help the new government to consolidate its political power. With the help of global societies for the domestic government establishment, Afghanistan needs global institutions like WTO to admit its government's status. Before this country had joined WTO, it was cooperating with the South Asian Association for Regional Cooperation (SAARC) to make Afghanistan realize the importance of trade. Joining the regional trade could be the step that provides more trade partners for it. Additionally, the cooperation has Preferential Trade Agreement (PTA) with India. Afghanistan's export value increased rapidly from 2016 to 2018 after entering WTO.

\section{WTO INSTITUTIONAL FRAMEWORK}

The WTO is a professional trade organization with a multilateral trade discipline framework and an effective dispute settlement mechanism, which is binding on its member states. As the only world institution with many reliable partners, it advocates a free economic system and plays an important role in regulation between states. After joining the WTO, Afghanistan has gained a lot of economic welfare. Under the impact of WTO, 
Afghanistan has gained more opportunities in economic trade.

Moreover, as a country with imperfect rules and regulations, joining the WTO could effectively urge Afghanistan to establish a set of regulations that comply with international market trade as soon as possible and supervise its implementation. Ahmad Jawed Sakhi and Arielle Berghammer-Ziegler pointed out that Afghanistan's compliance with International Road Transport (TIR) is a way for Afghanistan to effectively meet the requirements of the World Trade Organization's Trade Facilitation Agreement (TFA) [4]. It is necessary for Afghanistan to obtain TIR conventions and crossborder issues such as Central Asia. The benefits of new agreements such as transit agreements or South Asia Free Trade Agreements also require well-functioning and properly guided customs and tax systems. The establishment of such external-internal regulations would allow Afghanistan to stand at the starting point of international trade from the very beginning, because it is very likely to meet the requirements of the international market. Afghanistan's internal system would also undergone effective and rapid reforms along with regulations, avoiding possible mistakes.

Nadia Rocha argued that Afghanistan's production level is very backward, whose production capacity is insufficient with small domestic market as well as limited skills and capital endowments [5]. After joining the WTO, Afghanistan has more opportunities to produce and export dried fruits, carpets and other products that have competitive value in the international market. In addition, Afghanistan's mineral resources are also very rich, but due to lack of technology and equipment, they cannot mine on their own. However, as they have obtained more opportunities for international cooperation, they have signed contracts with other countries and used the technology and equipment of other countries for mining and utilization of mineral resources, which increases the income for the country.

Afghanistan's foreign direct investment (FDI) continues to grow. It is precisely due to the WTO's accession that Afghanistan's trade credit in the international market has increased. In this case, other countries are willing to believe that investment in Afghanistan will pay off. Besides, a feature of underdeveloped countries, cheap raw materials and labour costs, also attracts more FDI. In addition, Mobariz believes that the tourism industry in Afghanistan will also develop with Afghanistan's political and economic stability, attracting tourists from all over the world to travel that improves their economy [2].

Traditionally, Afghanistan has technical advantages in dried and handmade carpets, i.e., joining the WTO will take effect immediately. The mining of mineral resources will also benefit directly from the support of foreign technology and equipment. The norms and systems that
WTO member states must abide by also guarantee foreign direct investment.

Whereas, there are different ideas for the last point. In a short period of time, Afghanistan has not been able to develop rapidly and cannot launch distinctive and competitive tourism projects. People are also unlikely to choose Afghanistan as a tourist country because of their previous inherent impressions. Therefore, it may not have a significant impact on the tourism industry.

Regarding to calculate the benefits, Mobaris proposed a method to calculate the benefits of joining the WTO from the three combinations of consumers, producers, and government surpluses. For consumers, they can buy a variety of goods at low prices; for international producers, they can export their goods outside the Afghan market; with regard to domestic companies, their companies face Greater competition, which is not good for them. For the government, their income from low tariffs will be reduced.

We should admit that this argument is reasonable and powerful, because it analyses the economic situation based on different perspectives as well as the shortcomings and advantages of the business type. This argument also shows that the WTO's positive impact on LDC is limited, and it may even have a negative effect. It may lead to domestic bankruptcy and a reduction in government revenue. Regarding this negative impact, we believe that this does not mean that joining the WTO is a bad decision for LDC. At present, comparing the benefits and losses, the result is still that the advantages outweigh the disadvantages. Joining the WTO may be a good idea.

\section{IDEOLOGICAL CHANGE}

In this section, we try to explain the economic improvement through another perspective. As mentioned earlier, Afghanistan has more frequent trade activities after joining WTO. In the perspective of constructivism, Afghanistan's compliance and active participation can be attributed to the same value and goals with WTO membership and through interaction between states.

Before becoming a full member of WTO, Afghanistan has expressed its determination to join the WTO in order to fit in with it. According to wto.org, the advisor to the Deputy Minister of Commerce and Industry representing Afghanistan, acknowledged the importance of WTO membership for Afghanistan and was willing to contribute to advance the goals of the multilateral trading system, which is also the goal of WTO [6]. He also agrees that its WTO membership is the essential element of Afghanistan's effort to strengthen its trade and investment framework. Joining WTO can bring more opportunities to help Afghanistan improve economy and reduce poverty as well. Through the whole interaction process, Afghanistan actively got involved in WTO and multilateral trade cooperation. Similar idea 
also provides by Seddiqi that Afghanistan wants to expand the scope of international trade law from what limited by General Agreement on Tariffs and Trade to new activities by joining WTO, , e.g., foreign investment, trade in services, and intellectual property rights (IPRs) [7]. Hence, one indicates that Afghanistan has the same value and target with WTO membership. Based on constructivism's key point, Afghanistan involved as it recognized with the value and the identity as a WTO member, which makes the cooperation and compliance with the rules that WTO constituted, i.e., it has such an economic improvement.

After becoming a full member of WTO, Ministry of Industy and Commerce of Afghanistan has launched National Export Strategy (NES) to advance afghan Trade project, which is funded by the European Union and implemented by International Trade Centre [8]. Afghanistan's chief executive Abdullah comments that NES can be a guide map for the development of export performance and economic growth in the following five years, which will benefit its citizens for jobs and wealth creation. Besides, Afghanistan's minister of commerce and industries Rasaw points out that NES, as a policy tool, helps reduce the trade gap between imports and exports which could enhance the sustainable development. More importantly, Afghanistan's ITC executive director González approves NES as the move from planning to action. It represents the achievement of afghan governments effort in rebuilding the national economy and integrating into the world economic environment and the support from international community. These could reflect that Afghanistan government has a more positive attitude to multilateral trade performance after joining WTO and the NES can be a sign of the ideology change. Based on constructivism's key point, joining WTO could provide more horizontal view of international trade environment. The launch of the NES can be the practice of Afghanistan's ideology change which is to pay more attention to trade cooperation with other countries, to build the sustainable development of their own economy and to integrate into the world economic environment.

In conclusion, constructive perspective believes that Afghanistan's accession of WTO can be attributed to the same value and target. Analysing the public address by the representative of Afghanistan, it has a strong belief that WTO can bring more opportunity to achieve its goals of poverty reduction and economy improvement, which can also explain all the efforts that Afghanistan made in order to be a WTO member. Besides, the performance of Afghanistan after joining WTO can imply the ideology change that it has more positive attitude to global trading system and has already taken actions to integrate into it. The interaction process will result in the ideology change and has a further impact on Afghanistan's economic improvement.

\section{CONCRETE TRADE ACTIONS AND PERFORMANCE}

WTO, as an international and trusted institution, is playing a significant role in Afghanistan's economic development after this country had joined it. WTO is a reliable organization that provides high-quality information, helps countries to reduce the cost, and decrease the risk that countries would betray the agreements with each other. Looking at the Neo-liberal institutionalism theory, trade is a paramount part of countries' economic cooperation with others. In Hamed's work, he argues that international trade is important because it reduces countries' policies about the barriers of the trade as well as increases the free trade regulation and opportunities to most nations [9]. In Yenuu's view, through analyzing Ghana's case, international trade provides opportunities to trade economic growth, reduce residential poverty, offer technical assistance to improve the quality of good governance [10].

However, international trade might not inevitably bring considerable and expected growth to developing countries. From Irvin's work, more global trade to developing countries could cause a large growth informal economy to themselves (e.g., the illegal drug trades) which would not cause a positive effect to develop countries' economic market organization or their stable domestic development [11]. Irvin's view is just one possibility for developing countries' economic development through international trade. More and more developing countries prefer attracting Foreign Direct Investment (FDI). From Wadhwa's point of view, FDI is necessary for developing countries' economic development. The intrinsic is that it would enhance domestic welfare, improve the development of various skills, nation's capital, help with the latest invocation, also technology's transformation [12].

Dunning argues that there are four sorts of FDI, which are "market seeking, resource seeking, efficiencyseeking and strategic asset seeking" [13]. The resource seeking is a good option to explain and show Afghanistan as a developing country that attracts its FDI in the world. Afghanistan is a country with a bunch of cheap raw material and labour sources. Therefore, it attracts a lot of capital investment from other countries, such as building factories and producing goods in Afghanistan by paying a lower price of the raw material and labour than the other states. Moreover, the global trade from FDI in Afghanistan also brings this country to the latest technology and business strategy to accelerate the domestic economic development.

Price stated that India interested in Afghanistan's economic potential [14]. In June 2012, India hosted the Afghanistan Investment Summit in its own capital, Deli, to showcase the investment opportunities in Afghanistan to other "Heart of Asia" countries. And "mining, 
infrastructure, telecommunications, agriculture. Thereinto, small-scale industry, health, pharmaceuticals, education and information technology" are emerging sectors that India is very promising. This also indicates that Afghanistan needs vigorously developing these areas, and India has given Afghanistan the opportunity to obtain investment and development. Furthermore, Price also pointed out that India is an important donor country to Afghanistan. In 2011, Afghanistan and India signed a strategic partnership agreement. India pledged nearly 2 billion U.S. dollars in Afghanistan and spent approximately 1 billion U.S. dollars. This series of operations has made India the largest non-traditional donor country and the fifth largest bilateral donor country in Afghanistan.

It is a very important plan in terms of the current situation in Afghanistan. Nevertheless, we believe that India's donation may not be the best solution for Afghanistan since a country cannot rely solely on the donations of other countries for its development. This is also confirmed by India's gradual transformation of its status as a trading partner of Afghanistan. India's largest single activity in Afghanistan is the successful bid for the development of Hajigak iron ore by a consortium composed of seven Indian public and private companies, with a planned investment of US\$6.6 billion. Moreover, about 100 Indian companies have invested in Afghanistan since 2001. These corporations all denote that India is becoming an important trading partner of Afghanistan, which is becoming an independent country through trade.

\section{CONCLUSION}

In summary, it is benefit for Afghanistan's accession to the WTO from the perspective of Afghanistan's economy and trade enhancement as well as promoting the development of national trade. Specifically, we analysed and explained through five sections, which showed the extent to which Afghanistan's economy has improved and demonstrated the reasons in detail. Primarily, we introduced the economic background of Afghanistan before and after its accession to the WTO until now, which served as the basic information for this study. Then, the institutional framework of the WTO is presented in order to explain why Afghanistan's accession to the WTO has helped both the domestic and international economies. Subsequently, we discussed the change of ideology and analyse from the perspective of specific trade behavior and performance. Finally, suggestions and conclusions are put forward for further research in the future.

The reason why Afghanistan is taken as the study case to discuss the impact on economy and trade under the role of WTO is precisely because there are few studies related to WTO in LDC like Afghanistan. As well, the current international community for LDC to join the WTO is helpful to economic and trade disputes. Through the study of the impact of Afghanistan's accession to the international economic organization, some suggestions can be provided for the current relationship between the least developed countries and the WTO. It should be noted that our analysis is not completely comprehensive or accurate, and there are still many affecting factors that we cannot analyse at present. Meanwhile, we must admit that Afghanistan is not a universal case in the global economic system, though it is a very representative country. It is one-sided and limited to analyse the relationship between LDCs and international economic organizations only by Afghanistan.

In the future, for these limitations, one ought to study their development under the influence of WTO by analysing all other LDCs and make further research by comparing them with Afghanistan. In addition, this paper mainly studies the impact of WTO on Afghanistan in terms of the institution. Hence, it may also make an indepth analysis and discuss about other reasons promote the improvement of Afghanistan's international trade. In general, these results shed light for joining the WTO could still be a matter of greater advantages than disadvantages for the very least developed countries.

\section{REFERENCES}

[1] Data.worldbank.org. (2021) GDP (current US\$) Afghanistan | Data. [online] Available at: <https://data.worldbank.org/indicator/NY.GDP.M KTP.CD?locations=AF $>$ [Accessed 6 June 2021].

[2] Mobariz, A. S. (2015). Afghanistan's WTO accession: Costs, benefits and post-accession challenges (No. 147). ARTNeT Working Paper Series.

[3] TrendEconomy. (2021) Annual International Trade Statistics by Country (HSO2). Available at: https://trendeconomy.com/data/h2?commodity=TO TAL\&reporter $=$ Afghanistan\&trade_flow $=$ Export,I mport\&partner $=$ World\&indicator $=$ TV,YoY\&time period $=2008,2009,2010,2011,2012,2013,2014,201$ 5,2016,2017,2018,2019,2020[Accessed 26 April 2021].

[4] Ahmad Jawed Sakhi, Arielle Berghammer-Ziegler. (2018). Beyond WTO Accession: Next Steps in Afghanistan. Available at:https://chemonics.com/blog/beyond-wtoaccession-next-steps-afghanistan/[Accessed April 2021]

[5] Nadia Rocha. (2017). Trade as a Vehicle for Growth in Afghanistan: Challenges and Opportunities. World Bank, Washington, DC. (C) World Bank. Available at: https://openknowledge.worldbank.org/handle/1098 
6/28880 License: CC BY 3.0 IGO[Accessed 26 April 2021].

[6] Wto.org. (2021). WTO | 2015 News items Ministers approve Afghanistan's WTO membership at MC10. [online] Available at: <https://www.wto.org/english/news_e/news15_e/a cc_afg_17dec15_e.htm>[Accessed 26 April 2021].

[7] Seddiqi, H. (2020). Afghanistan legislative commitments to the WTO: A deeper look at Afghanistan's compliance with TRIPS. In Indiana Journal of Global Legal Studies (Vol. 27, Issue 2). https://doi.org/10.2979/indjglolegstu.27.2.0269

[8] Ministry of Industy and Commerce of Afghanistan. (2018). Afghanistan's National Export Strategy 2018-2020. Available at:https://www.intracen.org/uploadedFiles/intracen org/Content/Redesign/Projects/AAT/AFG_Main\% 20NES.pdf [Accessed 26 April 2021].

[9] Hamed K, Hadi D, Hossein K (2014) Export diversification and economic growth in some selected developing countries. African J Business Management 8: 700-704.

[10] Yennu, A. T. (2018). International Trade and Economic Growth in Ghana; Benefits, Constraints and Impacts. Sch J Appl Sci Res, 1, 18-22.

[11] Irvin BT (2014) Economics for today. 8th edn. University of North Carolina Charlotte, USA.

[12] Wadhwa, K., \& Reddy, S. S. (2011). Foreign direct investment into developing Asian countries: the role of market seeking, resource seeking and efficiency seeking factors. International Journal of Business and Management, 6(11), 219.

[13] Dunning, J. H. (1980). Towards an Eclectic Theory of International Production: Some Empirical Tests. Journal of International Business Studies, 11(1), 931.

[14] Price, G. (2013). India's policy towards Afghanistan (p. 10). London: Chatham House. 